\title{
Perancangan dan Pembuatan Serious Game Sebagai Simulasi Aktivitas Bisnis dan Akuntansi Menggunakan Pendekatan Agent-Based Modelling
}

\author{
(Design and Implementation Serious Game for Business and Accounting Activity Simulation using \\ Agent-Based Modelling Approach)
}

\author{
Angga Ari Wijaya, *Saiful Bukhori, Nelly Oktavia \\ Sistem Informasi, Program Studi Sistem Informasi, Universitas Jember (UNEJ) \\ Jln. Kalimantan 37, Jember 68121 \\ *E-mail: saiful.ilkom@unej.ac.id
}

\begin{abstract}
Abstrak
Permainan memiliki efek positif dalam mendukung kemampuan motorik seseorang untuk berkembang. Salah satu bahasan menarik dalam permainan adalah simulasi bisnis yang memiliki kategori serious game untuk dijadikan alternatif media pembelajaran dalam memahami konsep dasar bisnis dan aktivitas akuntansi. Gameplay dibuat dengan menciptakan artificial bisnis level UKM yang melakukan aktivitas jual beli, dimana di dalamnya terdapat game world, pelanggan dan toko yang berinteraksi untuk menghasilkan fenomena sebuah pasar. Aktivitas jual beli menjadi dasar siklus akuntansi untuk pemain belajar dan memahami kejadian finansial. Setiap agent diberi attribute yang digunakan sebagai parameter untuk membentuk personality-trait dan pengambilan keputusan pembelian serta aktivitas yang membentuk tingkah laku sehari - hari melalui State Machine dan Rule Based System (RBS). Simulasi perilaku konsumen dalam pasar virtual digunakan sebagai trigger aktivitas utama bisnis yaitu transaksi penjualan. Kejadian finansial yang terjadi dari proses simulasi menghasilkan proses jurnal untuk memberikan pemain pengalaman dalam memproses transaksi dengan contoh sumber aktivitas buatan.
\end{abstract}

Kata Kunci: Serious Game, Perilaku Konsumen, Agent-based Model, A Star, Stack Finite State Machine, Rule-Based System.

\begin{abstract}
Game has a positive effect in supporting people to develop theirs motor skills. One of the interesting topics in the game is a business simulation such a serious game category to be used as an alternative of learning in understanding the basic concepts of business and accounting activities. Gameplay is made by creating artificial of SME businesses that conduct trading activities, in which there are game world, customers and stores that interact to produce the phenomenon of a market simulation. Trading activity is the basis of accounting cycle for players to learn and understand financial flows. Each agent was given attribute is used as a parameter to build personality-trait and making purchasing decisions that make up the daily behavior through State Machine and Rule Based System (RBS). Simulation of consumer behavior in the virtual market is used as a trigger key business activity is the sale. Financial activity that occurred on the simulation produces journal transaction to give players experience post transactions with example.
\end{abstract}

Keywords: Serious Game, Consumer Behavior, Agent-based Model, A Star, Stack Finite State Machine. Rule-Based System.

\section{PENDAHULUAN}

Permainan atau game merupakan aktivitas interaktif yang dapat secara cepat memberikan umpan balik antara pemain dan sistem. Permainan simulasi bisnis dan akuntansi dapat memberikan lingkungan yang interaktif, bebas resiko, kondisi trial-error dalam mempelajari kejadian nyata serta dapat melakukan uji coba keputusan berdasarkan ilmu yang telah dipelajari sebelumnya. Simulasi dapat membuat pemain belajar mempertahankan kondisi keuangan atau membuat keputusan untuk mengurangi resiko finansial perusahaan. Pemain dapat belajar melalui penemuan, latihan, dan umpan balik daripada menyerap informasi sehingga lebih mudah melakukan transfer pengetahuan yang mereka dapatkan dari pengalaman bermain ke dunia kerja sesungguhnya [2].

Kata "serious" secara umum mengacu pada produk yang biasa digunakan pada industri seperti pertahanan, edukasi, eksplorasi sains, kesehatan, perancangan kota, rekayasa, agama dan politik. Serious game bukan sebuah genre tapi kategori yang didalamnya dapat termasuk jenis advergame, political game, educational game [8]. Game bisnis telah banyak berkembang dipasaran, beberapa yang cukup familiar adalah Lemonade Tycoon, Sim City, Transportation Tycoon, Roller-coaster Tycoon, Big Business Social Game dan lain sebagainya. Konsep yang dibuat selalu melibatkan simulasi artificial life dengan menciptakan sebuah tempat sebagai refleksi aktivitas dunia nyata.

Sebagian besar manusia lebih mudah mengingat suatu hal ketika mereka melihat dan diberi gambaran atau terlibat langsung didalamnya. Hal ini menunjukkan pentingnya visualisasi nyata bagi manusia untuk memahami sesuatu, demikian juga dalam proses belajar mengajar [7]. Beberapa mata pelajaran disajikan dalam bentuk abstrak dimana dalam kondisi sesungguhnya terdapat proses dan aktivitas 
fisik yang perlu diketahui sebagai bentuk pengalaman untuk dapat mengerti bagaimana bentuk implementasi ilmu tersebut. Sistem komputer seperti simulasi dan animasi dapat memberikan pengalaman belajar yang kongkrit kepada siswa [11].

Ulbinaite pernah menuliskan simulasi keputusan pembelian berbasis agent-based model yang dikembangkan menggunakan program NetLogo dengan memodelkan perilaku konsumen menjadi persamaan matematis [16]. Penelitian ini memodelkan perilaku menjadi aturan dan fungsi motivasi. Membuat game simulasi yang interaktif dibutuhkan kombinasi konsep social life sebagaimana makhluk hidup yang memiliki peran dan aktivitas lain. Simulasi bisnis dibentuk dari ide sederhana, diciptakan tempat dalam bentuk kota yang memiliki beberapa district kemudian diletakkan toko pemain dan kompetitor yang bersaing untuk memperoleh market share terbanyak melalui pengaturan atribut toko seperti harga, kualitas, promosi, lingkungan dan pelayanan.

\section{Identifikasi Masalah}

Serious game telah berkembang pesat sebagai alat atau media alternatif dalam bidang bisnis dan edukasi, seperti advergame dan training game dimana fokus yang menjadi perhatian saat ini adalah pengembangan konten yang dapat menyampaikan tujuan dari simulasi itu sendiri. Aktivitas konsumen sangat dinamis dan penuh unsur ketidakpastian. Proses pemilihan sebuah produk melibatkan banyak hal yang dipertimbangkan oleh konsumen, terutama dari aspek emosi yang sulit diukur. Unsur eksternal seperti lingkungan dapat menghasilkan influence, pengalaman, atau bahkan kecelakaan pemilihan produk oleh pelanggan. Tujuan dari penelitian ini adalah menghasilkan model simulasi yang dapat menunjukkan tingkat pertumbuhan dan persaingan toko dalam lingkungan permainan serious game. Penelitian yang dilakukan sebatas pembuatan model interaksi konsumen dan lingkungan terhadap produk secara sederhana. Validasi model hanya dilihat dari tingkat logis tidaknya sebuah aturan dan fungsi motivasi bekerja sesuai aturan di dunia nyata.

\section{METODE PENELITIAN}

Pengembangan serious game berbasis agent menggunakan pendekatan MASIM yang biasa digunakan dalam pengembangan simulasi multi-agent, MASIM merupakan akronim dari Multi-Agent Simulation Methodology. Konsep metodologi ini dibagi menjadi 5 tahapan, yaitu requirement atau pembentukan scenario dan ide. Pada kasus simulasi marketplace, requirement adalah kegiatan jual beli dan interaksi pelanggan. Berikutnya adalah modeling, yaitu membuat model abstrak dari ide simulasi agent yang dibuat, kemudian design and architectural yang lebih dekat dengan desain dan program atau proses teknis tentang bagaimana fungsi atau aturan setiap agent dibuat. Selanjutnya fase implementation yaitu pembuatan simulasi dengan bahasa pemrograman. Terakhir adalah verification, validation dan accreditation yaitu fase membandingkan hasil requirement dan hasil implementasi, atau melihat bagaimana hasil simulasi bekerja dengan model sesungguhnya di dunia nyata [4].

Istilah agent sendiri merupakan kumpulan entitas yang dapat mengambil keputusan secara mandiri. Setiap agent bertindak dan berperilaku berdasarkan aturan tertentu di dalam lingkungannya. ABM dapat dijadikan alat untuk memodelkan sistem dunia nyata yang kompleks. Paper ini memberi gambaran tentang agent-based modeling dan bagaimana cara mengembangkannya, khususnya dalam pembentukan model marketplace dan perilaku konsumen [10].

\section{Desain dan Perancangan Game}

Pengembangan serious game ini melalui tahapan modelling dan design architectural seperti abstraksi model serious game yang dibuat, pembuatan game world, penentuan state dan aturan agent.

\section{Serious Game Model}

Serious game berfokus pada pengembangan game world dan simulasi aktivitas pembelian. Gambar 1 merupakan model aktivitas simulasi. Agent adalah objek yang memiliki trait dan behavior. Trait berhubungan dengan identitas dan variabel yang digunakan untuk menyimpan informasi, behavior merupakan bagian yang mengatur pergerakan dan interaksi. Data trait dan behavior digunakan sebagai pengetahuan atau fakta oleh rule-set. Rule sendiri terpisah dalam bentuk atomic, memiliki index dan prioritas yang digunakan oleh sistem pengatur konflik dalam inference engine.

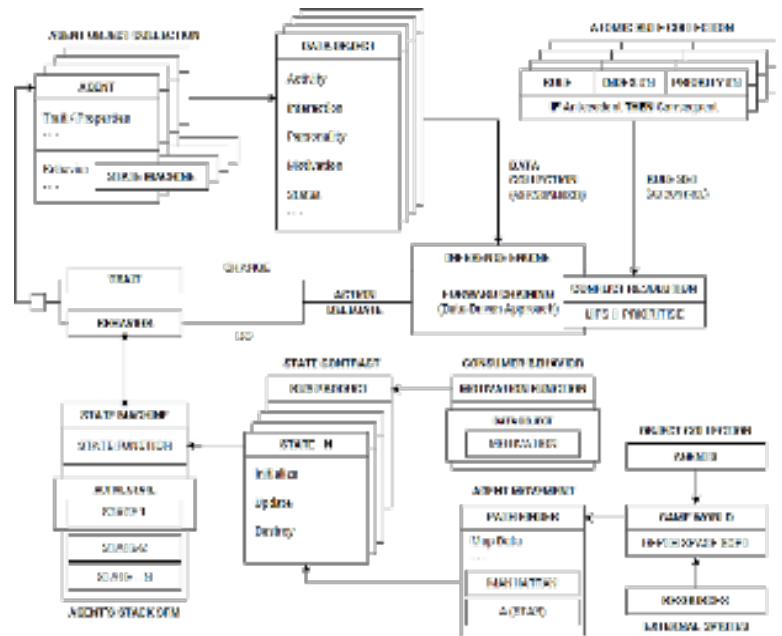

Gambar 1 Model serious game bisnis

Hasil rule-based menghasilkan sebuah action delegation dalam bentuk 2 hal yaitu perubahan nilai dari atribut trait agent atau perubahan behavior. Perubahan state ditangani oleh state machine. Setiap state memiliki ketergantungan pada modul path finder untuk memberikan kemampuan bergerak pada agent melalui algoritma $\mathrm{A}^{*}$ (star). Penentuan pemilihan produk oleh agent ditentukan oleh modul motivation function yang menghitung tingkat ketertarikan agent dengan produk yang ditawarkan. Setiap agent memiliki siklus hidup yang sederhana yaitu hidup, mengerjakan primary action sesuai peran, mengerjakan secondary action jika diperlukan dan melakukan interruption action untuk pemilihan produk kemudian mati. Siklus hidup agent dapat dilihat pada Gambar 2. 


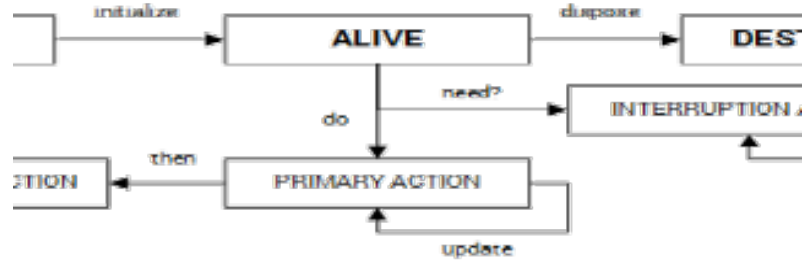

Gambar 2 Siklus hidup agent

Penelitian ini merancang simulasi dengan 3 prinsip dasar yaitu agent harus memiliki aktivitas rutin sebagai bentuk dasar kehidupan, agent harus memenuhi aktivitas yang berhubungan dengan perilaku konsumen, dan agent harus memiliki perilaku yang mengisi ruang ketidakpastian dalam bertindak dan berinteraksi untuk memunculkan fenomena stokastik atau accidental activity.

\section{Gameworld}

Dunia game yang akan dibangun mengambil sudut pandang isometric $2 D$, proyeksi ini memberikan visualisasi 3 D yang dibentuk secara 2D. Game world direpresentasikan dalam bentuk array 2D [3]. Map dibentuk menggunakan array $25 \times 30=750$ coordinate yang terdiri dari 93 tile element. Map level dibagi menjadi 3 layer, yaitu background layer untuk base tile yang statis, kemudian level layer yang digunakan untuk obstacle seperti gedung, rumah, toko dan agent, terakhir overlay layer untuk particle dan sprite tambahan seperti yang ditunjukkan oleh Gambar 3.
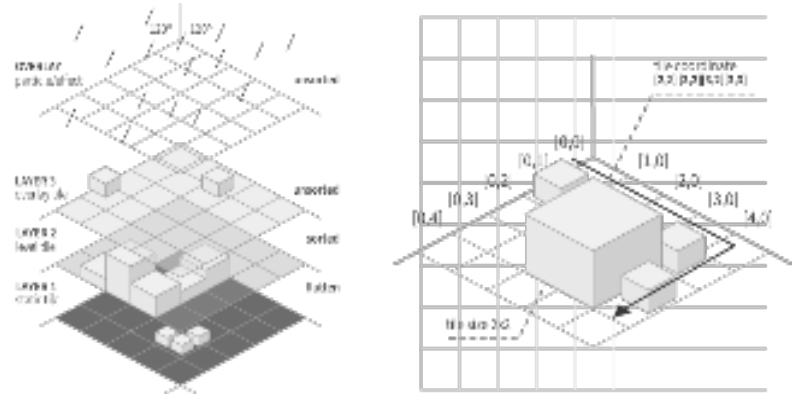

Gambar 3 Game world isometric dan depth sorting

Depth space sort merupakan teknik untuk mengurutkan kedalaman dari komponen isometric $2 D$, dimana objek yang memiliki atribut $y$ paling rendah harus diletakkan terlebih dahulu diikuti oleh atribut $x$ yang lebih rendah [9]. Depth sort secara sederhana melakukan swap object dengan mengurutkan z-index secara berurut. Teknik pengurutan dapat dilakukan menggunakan algoritma insertion-sort.

\section{Steering behavior dan Path finding}

Steering behavior merupakan kemampuan agent untuk bergerak di dalam game world. Agent diberikan kemampuan untuk mencari jalan dengan metode path following yang dibangkitkan menggunakan algoritma $A^{*}$ (Star) [17]. Dalam notasi matematika, algoritma A* ditulis $f(n)=g(n)+h(n)$ [5]. Biaya perkiraan $h(n)$ biasa disebut nilai heuristic, pada penelitian ini nilai heuristic didapat menggunakan teknik manhattan distance [12]. Nilai heuristic manhattan didapat dengan formula $\mathrm{H}=10 *$ (abs (current - targetX) + abs (currentY - targetY). Gambar 4 menunjukkan contoh bagaimana algoritma agent mencari jalan dari koordinat $[1,3]$ menuju [5, 3]. Misalkan cost untuk bergerak antar node secara horisontal dan vertikal adalah 10, kemudian bergerak secara diagonal 14 .

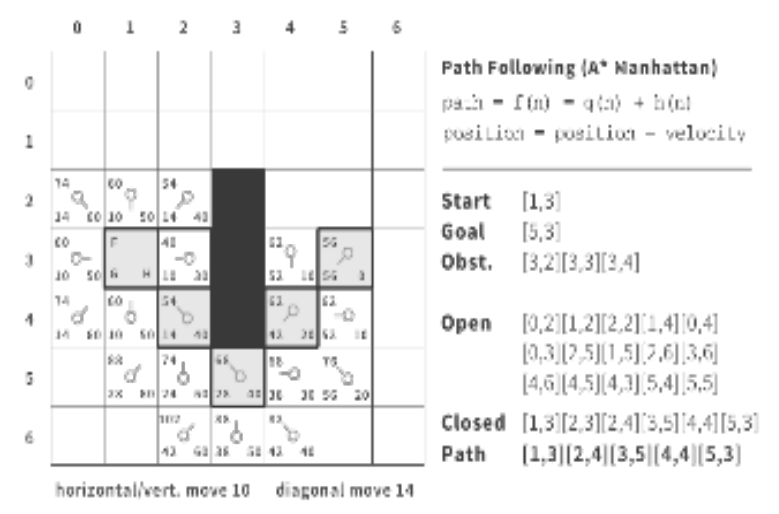

Gambar 4 Steering behavior dan path finding

Algoritma A* memiliki dua senarai yaitu open dan closed. Terdapat 3 kondisi bagi setiap node yang dibangkitkan, yaitu sudah berada di open, sudah berada di closed dan tidak pernah di keduanya. Best node dipilih dari open yang memiliki nilai $f$ terkecil untuk dipindahkan ke closed, cek semua child yang pernah dibangkitkan apakah pernah di open atau closed, kemudian update nilai $f$ jika jalur yang melewati best node saat ini lebih kecil dari pada melalui parent sebelumnya. Teruskan iterasi rekursif hingga ditemukan ketika best node sama dengan goal kemudian lakukan tracing node mundur untuk mendapatkan path dari start ke goal. Pada kasus ini dengan memperbolehkan agent bergerak secara diagonal maka didapat path $[1,3]$ $[2,4][3,5][4,4][5,3]$. Hasil path dari algoritma $A$ star menjadi jalur agent untuk menjelajahi map secara point-topoint.

\section{Stack Finite State Machine}

Finite state machine merupakan pemodelan matematika yang biasa digunakan program computer dan sirkuit logika sekunsial. Setiap mesin hanya memiliki satu state aktif, setiap state dapat berpindah (transition) ke state lain sesuai dengan urutan dan logika program [18]. State machine dapat digunakan sebagai kontrol perilaku agent yang dibagi menjadi beberapa bagian kecil agar mudah didefinisikan [14].

Pengembangan FSM dalam penelitian ini menggunakan teknik stack untuk melakukan manajemen state. Sebuah state dapat diinterupsi oleh state lain tanpa menghapus kondisi terakhir state tersebut. Pertama kita mendefinisikan semua aktivitas agent selanjutnya kita mengelompokkan state yang sejenis menjadi state yang lebih umum. Kedua kita membuat transisi antar state dan desain state machine seperti pada Gambar 5. Agent didefinisikan menjadi 4 jenis peran yaitu worker, student, trader dan freeman. Agent memiliki state khusus yaitu "Buy Product", tahapan state ini merupakan representasi aktivitas dari model perilaku konsumen mulai dari pengenalan masalah, pencarian informasi, pemilihan alternatif, proses pembelian, dan evaluasi hasil pembelian yang nantinya akan diproses oleh motivation function [6]. 


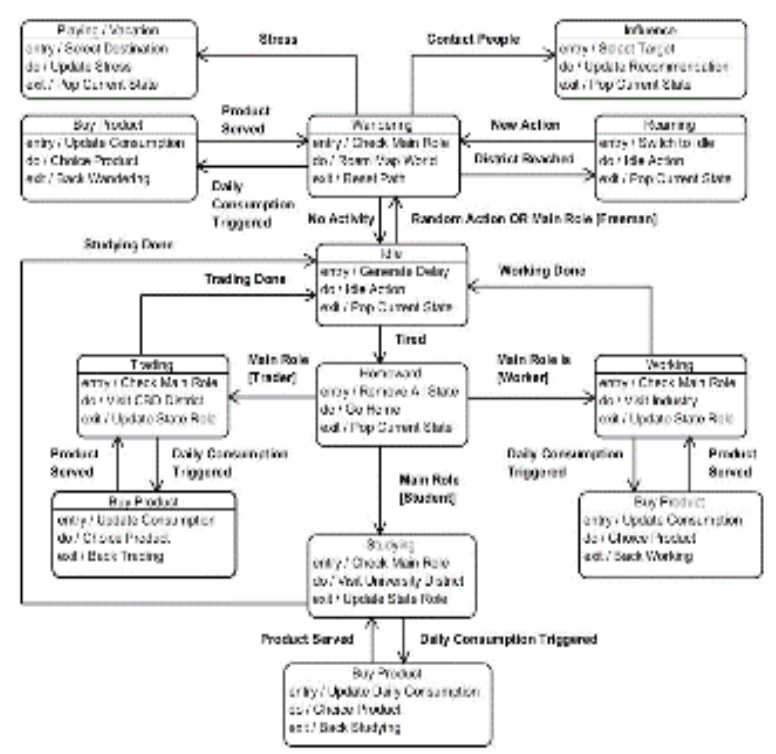

Gambar 5 State machine aktivitas agent

\section{Atribut Agent}

Konsep utama dari tingkah laku agent dibentuk melalui sebuah ide yang merepresentasikan sebuah motif. Motif timbul dari proses bagaimana seseorang memiliki keinginan dan seberapa besar mereka mencoba untuk mewujudkannya. Parameter yang digunakan dalam simulasi meliputi atribut konsumen, toko, dan lingkungan yang mempengaruhi pengambilan keputusan pembelian seorang konsumen. Pembentukan atribut konsumen berdasarkan sikap dan perilaku individu yang melekat pada diri manusia yang didasari oleh [6]:

1. Lingkungan: Rekomendasi dan penolakan lingkungan.

2. Perbedaan individu: Sumberdaya konsumen, motivasi keinginan, pengetahuan, gaya hidup, kepribadian yang dibentuk dari informasi demografi.

3. Psikologi: Kemampuan pengolahan informasi, perilaku, emosi.

Atribut yang yang dijelaskan oleh Engel et al dimasukkan dalam model pembentukan karakter konsumen dalam game. Tabel 1 merupakan atribut agent konsumen yang menghimpun kepribadian, aksi, informasi interaksi dengan game world dan variabel tambahan untuk membuat agent dapat bekerja dalam simulasi.

Tabel 1 Atribut agent konsumen

\begin{tabular}{lll}
\hline Attribute & Type & $\begin{array}{l}\text { Initial } \\
\text { value }\end{array}$ \\
\hline Agent Activity & & - \\
\hline action & StateMachine & \\
\hline Agent Interaction & & $1-2$ \\
\hline speed & Float & {$[0,0]$} \\
\hline position & Point & {[]} \\
\hline path & Vector Data & {[]} \\
\hline destination & Point & 0 \\
\hline dX & Float & 0 \\
\hline Agent Personality & Float & \\
\hline agentId & & 1-Pop. \\
\hline district & Integer & Pseudo-rand \\
\hline
\end{tabular}

\begin{tabular}{lll}
\hline mainRole & Enumeration & Pseudo-rand \\
\hline buyingPower & Integer & $1-10$ \\
\hline emotion & String & $1-10$ \\
\hline education & Integer & $1-10$ \\
\hline art & Integer & $1-10$ \\
\hline athletic & Integer & $1-10$ \\
\hline Agent Motivation & & \\
\hline priceSensitivity & Float & $1-100$ \\
\hline qualitySensitivity & Float & $1-100$ \\
\hline recommendation & Float & $1-10$ \\
\hline disqualification & Float & $10-$ rcmd \\
\hline environmentEval. & Vector Data & Pseudo-rand \\
\hline productEval. & Vector Data & Pseudo-rand \\
\hline adverEval. & Vector Data & Pseudo-rand \\
\hline respondEval. & Vector Data & Pseudo-rand \\
\hline Agent Other Attribut & & \\
\hline choice & Enumeration & 0 \\
\hline consumption & Integer & $1-4$ \\
\hline stress & Integer & Pseudo-rand \\
\hline health & Integer & Pseudo-rand \\
\hline
\end{tabular}

Toko memilik atribut yang dinilai oleh konsumen dan memberikan pengaruh melalui promosi untuk memperkenalkan produk dan memberi stimulti terhadap konsumen. Berikut ini adalah komponen toko sebagai artificial market [6]:

1. Produk: Barang atau jasa yang dijual oleh toko

2. Kualitas: Multi demensi nilai yang melekat di produk

3. Lokasi: Tempat toko secara fisik atau non fisik

4. Situasi: Dekorasi, aroma, cahaya, cuaca, kebersihan

5. Komunikasi: Promosi, pelayanan pegawai.

Komponen toko membentuk atribut toko keseluruhan. Atribut toko dibagi menjadi product, environment, dan service seperti yang dapat dilihat pada Tabel 2.

Tabel 2 Atribut agent toko

\begin{tabular}{lcc}
\hline Attribute & Type & Initial value \\
\hline shopId & Integer & Pseudo-rand \\
\hline district & String & 0 \\
\hline Product & & \\
\hline advertising & ector Data & 0 \\
\hline price & Vector Data & 0 \\
\hline quality & Vector Data & 0 \\
\hline Environment & & \\
\hline decoration & Vector Data & {$[1,1,1]$} \\
\hline cleaness & Vector Data & {$[1,1]$} \\
\hline scent & Vector Data & {$[1,1,1]$} \\
\hline Service & & \\
\hline productivity & Integer & 0 \\
\hline morale & Integer & 0 \\
\hline service & Integer & 0 \\
\hline
\end{tabular}

Lingkungan atau game world memiliki atribut untuk pembangkitan aktivitas konsumen. Lingkungan memberikan peran sebagai media antar agent berinteraksi, memberikan akses ke sebuah lokasi, memberikan situasi yang dinamis dan hidup. Atribut ini dapat dilihat pada Tabel 3 yang dibagi menjadi 2 jenis yaitu global merupakan atribut yang berlaku untuk semua kondisi simulasi dan 
local merupakan atribut yang berisi data informasi district beserta informasi yang ada didalamnya.

Tabel 3 Atribut lingkungan

\begin{tabular}{lcc}
\hline Attribute & Type & Initial value \\
\hline Global & & \\
\hline day & Integer & 1 \\
\hline time & Integer & 3 \\
\hline weather & Vector Data & Pseudo-rand \\
\hline event & Vector Data & Pseudo-rand \\
\hline Local & & \\
\hline district & Enumeration & {[]} \\
\hline popularity & Float & {[]} \\
\hline cost & Integer & {[]} \\
\hline
\end{tabular}

Atribut dari teori - teori tersebut kemudian dimodelkan dalam agent konsumen, toko dan lingkungan. Berdasarkan teori marketing, kunci stimuli memulai konsumen untuk membuat keputusan pembelian dalam lingkungan bisnis yang kompleks melalui penilaian atribut yang melekat pada agent sebagai berikut [1]:

1. Harga produk

2. Kualitas produk

3. Promosi toko

4. Pelayanan toko

5. Rekomendasi dan penolakan dari lingkungan

6. Pengalaman pembelian sebelumnya

\section{Motivasi Konsumen}

Keputusan yang diambil seorang agent merupakan pilihan dari derajat motivasi tertinggi dari produk yang ditawarkan. Fungsi motivasi ini diambil dari Keputusan pembelian adalah proses kognitif dari stimulti dan personality yang dapat didefinisikan dengan melihat kedekatan ketertarikan agent terhadap suatu produk dibandingkan dengan produk yang lain. Penelitian (Kim, Blattberg, \& Rossi, 1995) menunjukkan bahwa price sensitivity merupakan fungsi eksponensial dari perbedaan antara harga riil produk dan harga yang diharapkan dari produk, artinya nilai ketertarikan variabel harga bergantung dari seberapa rendah konsumen sensitif terhadap harga yang semakin tinggi [19]. Sehingga motivasi pembelian produk terhadap harga adalah:

$$
P S_{i}=-\alpha^{P_{i}-P_{e}}+k
$$

Dimana $a$ adalah parameter buying power, $\mathrm{k}$ adalah konstanta dari atribut socio-economic yaitu price sensitivity yang dan $P_{e}$ adalah harga yang diharapkan agent dari produk. Nilai $P_{e}$ sulit untuk ditentukan, sehingga diganti dengan harga rata - rata dari harga semua produk, sehingga persamaannya menjadi:

$$
\begin{gathered}
P_{e}=P_{\text {ave }}=\frac{1}{N} \sum_{i=1}^{N} P_{i} \\
P S_{i}=-\alpha^{P_{i}-P_{\text {ave }}}+k
\end{gathered}
$$

Sensitivitas harga kemudian dikalikan dengan harga produk yang dibandingkan yaitu $P_{i}$. Berikutnya adalah motivasi pembelian produk terhadap kualitas, sedikit berbeda dengan harga, kualitas adalah variabel multidimensi, karena produk memiliki kualitas dari berbagai aspek, misalnya pada makanan adalah rasa, wadah, aroma, tampilan, dan kebersihan. Jadi misalkan produk $j$ memiliki $m$ kualitas, maka secara keseluruhan produk $;$ pada model dapat di hitung dari rumus motivasi [19]:

$$
Q_{i}=\sum_{j=1}^{m} W_{j} Q_{i j}
$$

Dimana $Q_{i j}$ adalah produk $i$ kualitas $j$, dan $W_{j}$ digunakan untuk mengukur seberapa penting $Q_{i j}$ terhadap agent, dalam psychological theory [13] menyarankan bahwa, ketika konsumen memilih sebuah produk, semakin dekat kualitas merek sesuai yang diharapkan konsumen, semakin sensitif konsumen pada kualitas merek ini. Berikutnya untuk kualitas produk menjadi:

$$
Q S_{i}=\beta^{\left|Q_{i}-Q_{e}\right|}+L
$$

Dimana $Q S_{i}$ adalah parameter quality sensitivity yang dipicu oleh produk $i$ kualitas $Q_{i}, \quad \beta$ adalah parameter buying power yang dimiliki agent, dan $L$ adalah atribut socio-economic yaitu quality sensitivity. Konsumen dari sosial kelas atas lebih memperhatikan kualitas dari sebuah barang dan pelayanan ketika melakukan keputusan pembelian. $Q_{e}$ adalah kualitas yang diharapkan agent dari produk yang dapat digantikan dengan kualitas rata - rata dari semua, sehingga hasilnya adalah:

$$
\begin{gathered}
Q_{e}=Q_{a v e}=\frac{1}{N} \sum_{i=1}^{N} Q_{i} \\
Q S_{i}=\beta^{\mid Q_{i}-Q_{a v e}}+L
\end{gathered}
$$

Berikutnya adalah penilaian promosi terhadap pengetahuan agent dalam menerima stimulus iklan. Promosi juga miltidimensi variabel yang memiliki penilaian kepentingan dari personality-trait agent sehingga motivasi agent terhadap promosi produk i dikalikan dengan kerentanan agent ${ }_{s u} s_{i}$ dalam menerima promosi adalah:

$$
\text { adve } r_{i}=s u s_{i} \times\left(\sum_{j=1}^{m} W_{j} a d_{i j}\right)
$$

Terakhir adalah penilaian kecenderungan agent $f t_{i}$ untuk terpengaruh rekomendasi dan diskualifikasi agent lain terhadap pengaruh (influence) yang diterima in $l_{i}$. Penilaian agent terhadap influence didapatkan dari:

$$
\text { INF } L_{i}=f t_{i} \times \text { in } f l_{i}
$$

Sehingga sebuah agent melakukan keputusan pembelian final berdasarkan motivasi tertinggi dari pilihan toko atau produk yang ada. ketika semua persamaan digabung maka formula motivation function adalah:

$$
\begin{gathered}
M_{i}=P S_{i} \times P_{i}+Q S_{i} \times Q_{i}+\text { sus }_{i} \times a d_{i}+f t_{i} \times \text { in } f l_{i} \\
\max \left\{M_{1}, M_{2}, M_{3} \ldots, M_{i}\right\}
\end{gathered}
$$

Produk yang dapat memberikan derajat motivasi terbesar dari motivation akan menjadi pilihan sesuai dengan hasil $\max \left(M_{i}\right)$.

\section{Pembentukan Rule-based System}

Pengambilan keputusan berbasis rule merupakan bidang ilmu reasoning dalam AI. Reasoning merupakan teknik penyelesaian masalah dengan merepresentasikan masalah ke dalam basis pengetahuan (knowledge base) 
menggunakan logic atau bahasa formal [15]. Rule based system memiliki 2 bagian utama yaitu database yang berisi knowledge dan kumpulan aturan "if - then". Penelitian ini mencoba membangun rule yang memicu transisition pada state machine. Rule-based system membuat tingkah laku agent didefinisikan mirip bahasa manusia menggunakan terminologi jika-maka. Tabel 4 menunjukkan aturan umum dari agent yang berinteraksi dengan lingkungannya.

Tabel 4 Rule set agent

\begin{tabular}{lc}
\hline \multicolumn{1}{c}{ Rule } & Target \\
\hline Jika [lapar] maka [makan] & Semua Agent \\
\hline $\begin{array}{l}\text { Jika [cuaca bagus] } \\
\text { maka [pergi keluar rumah] }\end{array}$ & Semua Agent \\
\hline $\begin{array}{l}\text { Jika [tidak ada kegiatan] } \\
\text { maka [wandering] }\end{array}$ & Semua Agent \\
\hline $\begin{array}{l}\text { Jika [bertemu orang] } \\
\text { maka [influence] }\end{array}$ & Semua Agent \\
\hline $\begin{array}{l}\text { Jika [stress] } \\
\text { maka [bermain] atau [berlibur] }\end{array}$ & Semua Agent \\
\hline $\begin{array}{l}\text { Jika [suka event] } \\
\text { maka [pergi ke lokasi event] }\end{array}$ & Semua Agent \\
\hline $\begin{array}{l}\text { Jika [task selesai] } \\
\text { maka [pulang kerumah] }\end{array}$ & Semua Agent \\
\hline $\begin{array}{l}\text { Jika [low health] } \\
\text { maka [pergi ke rumah sakit] } \\
\text { atau [pulang ke rumah] }\end{array}$ & Semua Agent \\
\hline $\begin{array}{l}\text { Jika [hari libur] } \\
\text { maka [diam dirumah] } \\
\text { atau [berlibur] atau [wandering] }\end{array}$ & Semua Agent \\
\hline $\begin{array}{l}\text { Jika [di rumah] atau [rumah sakit] } \\
\text { maka [heatlh+] dan [emosi+] }\end{array}$ & Semua Agent \\
\hline $\begin{array}{l}\text { Jika [cuaca buruk] } \\
\text { maka [health-] }\end{array}$ & Semua Agent \\
\hline $\begin{array}{l}\text { Jika [pergi bermain] atau [berlibur] } \\
\text { maka [stress-] }\end{array}$ & Semua Agent \\
\hline $\begin{array}{l}\text { Jika [emosi low] atau [stress high] } \\
\text { maka [accidental+] }\end{array}$ & Semua Agent \\
\hline $\begin{array}{l}\text { Jika [wandering] } \\
\text { maka [health-] dan [stress-] } \\
\text { maka [health+] dan [emosi+] }\end{array}$ & \\
\hline
\end{tabular}

\begin{tabular}{ll}
\hline EXTEND FREEMAN & \\
\hline $\begin{array}{l}\text { Jika [tidak ada kegiatan] } \\
\text { maka [wandering] }\end{array}$ & Freeman \\
\hline $\begin{array}{l}\text { Jika [bosan] } \\
\text { maka [pergi ke airport untuk exit] }\end{array}$ & Freeman \\
\hline $\begin{array}{l}\text { Jika [lapar] } \\
\text { maka [makan pilih random] }\end{array}$ & Freeman \\
\hline $\begin{array}{l}\text { Jika [bertemu orang] } \\
\text { maka [influence pilih random] }\end{array}$ & Freeman \\
\hline
\end{tabular}

\begin{tabular}{ll}
\hline EXTEND TRADER & \\
\hline $\begin{array}{l}\text { Jika [jam 9] } \\
\text { maka [pergi ke time square] }\end{array}$ & Trader \\
\hline $\begin{array}{l}\text { Jika [jam 20] } \\
\text { maka [pulang kerumah] }\end{array}$ & Trader \\
\hline Jika [trading] & Trader \\
\hline
\end{tabular}

\begin{tabular}{ll}
\hline maka [stress+] & Trader \\
\hline $\begin{array}{l}\text { Jika [jam 9] } \\
\text { maka [pergi ke time square] }\end{array}$ & \\
\hline & \\
\hline EXTEND STUDENT & Student \\
\hline $\begin{array}{l}\text { Jika [jam 7] } \\
\text { maka [pergi ke district school center] }\end{array}$ & Student \\
\hline $\begin{array}{l}\text { Jika [jam 1] } \\
\text { maka [pulang ke rumah] }\end{array}$ & Student \\
\hline $\begin{array}{l}\text { Jika [hari munggu] } \\
\text { maka [tetap dirumah] }\end{array}$ & Student \\
\hline \begin{tabular}{l} 
Jika [study] maka [stress+] \\
\hline $\begin{array}{l}\text { Jika [jam 8] } \\
\text { maka [pergi ke district factory] }\end{array}$
\end{tabular} \\
\hline $\begin{array}{l}\text { Jika [jam 16] } \\
\text { maka [pulang kerumah] }\end{array}$ & Worker \\
\hline $\begin{array}{l}\text { Jika [hari sabtu] atau [minggu] } \\
\text { maka [tetap dirumah] }\end{array}$ & Worker \\
\hline $\begin{array}{l}\text { Jika [bekerja] } \\
\text { maka [stress+] }\end{array}$ & Worker \\
\hline
\end{tabular}

Agent memiliki jenis motif dalam mengolah informasi sebagai acuan pemilihan produk. Penilaian informasi terhadap motif pembelian membagi agent menjadi 3 yaitu:

1. Optimistic agent: yaitu individu yang melakukan pemilihan produk berdasarkan motivasi tertinggi dari penilaian yang dilakukan.

2. Pessimistic agent: yaitu individu yang melakukan pemilihan produk dari influence atau pengaruh rekomendasi dan promosi agent lain.

3. Neutral agent: adalah agent yang melakukan kecelakaan pembelian. Pilihan agent di ambil dari salah satu atribut seperti berdasarkan toko terdekat, harga termurah, kualitas tertinggi, toko dengan iklan paling intense, toko paling populer, pelayanan terbaik, lingkungan paling sesuai dan pilihan acak.

Implementasi simulasi tentu saja tidak bisa mencakup semua hal dalam dunia nyata, untuk itu perlu membuat asumsi dan batasan untuk permasalahan yang dimiliki agent.

1. Populasi yang ada di game world dianggap konstan, sehingga proses tambahan agent dari luar district yang ada atau kasus migrasi diabaikan.

2. Populasi dianggap homogen, setiap individu memiliki peluang yang sama untuk memilih produk, melakukan rekomendasi dan diskualifikasi terhadap agent lain.

3. Individu dalam populasi dapat berinteraksi tanpa melihat kelompok tertentu sesuai asumsi pada poin 1 .

4. Simulasi dilakukan dalam 1 siklus yang merepresentasikan 1 hari.

5. Agent memiliki arah pergerakan secara mandiri, tidak dipengaruhi oleh agent lain melalui kemampuan steering behavior dan data atribut interaction.

a. Konstruksi aturan pergerakan individu berdasarkan prinsip autonomus agent

Pergerakan agent dipengaruhi oleh lokasi, arah gerak, hasil path finding dari koordinat tujuan yang akan dicapai. 
Aturan yang diberikan merupakan sebuah aktivitas sederhana yang dibangkitkan sesuai peran atau jenis agent.

1. Bangkitkan agent di lokasi district sesuai personality trait yang dimiliki.

2. Cek variable hari, waktu dan cuaca terhadap kemungkinan agent untuk melakukan aktivitas utama sesuai peran yang dimiliki.

3. Cek kemungkinan accidental action terpenuhi sehingga agent melakukan aktivitas yang bertolak dari keputusan normal.

4. Jika agent memutuskan melakukan aktivitas utama sesuai role, berikan state dan koordinat tujuan district untuk menyelesaikan aktivitas utama tersebut.

5. Jika aktivitas utama selesai dilakukan, cek status emosi, stress dan health agent.

6. Berikan tujuan sesuai probabilitas status agent terhadap lokasi baru yang akan menjadi tujuan selanjutnya.

7. Selama proses simulasi satu siklus, cek state interupsi konsumsi produk.

8. Jika state konsumsi produk aktif hitung motivation agent terhadap pilihan produk yang ada dari semua toko yang memiliki produk sejenis.

Ruleset aktivitas adalah kumpulan aturan yang memberikan agent pergerakan di game world. Rule-based system melakukan trigger untuk menjalankan main task, influence, pergi ke event, bermain, dan pulang kerumah. Aturan ini di eksekusi dengan syarat yang diciptakan dari (1) main role agent, (2) status cuaca yang dapat diterima agent, (3) karakteristik event, (4) status stress dan health agent, (5) probabilitas terjadi accidental, (6) determined dari agent untuk berpindah state, (7) world phase atau time saat ini yang berlaku di game world. Gambar 6 merupakan kerangka dari rule set perilaku agent di game world.

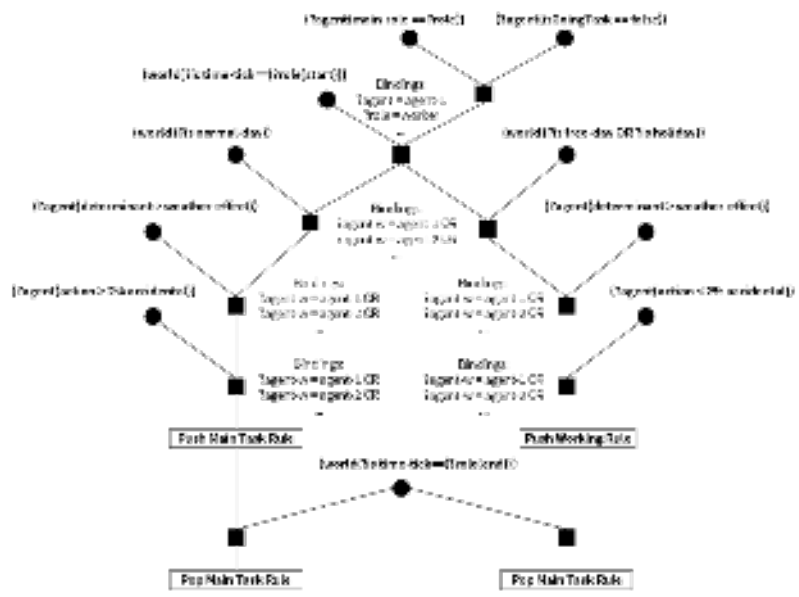

Gambar 6 Rule dan interaksi agent

Influence adalah state interupsi yang memungkinkan agent memberikan pengaruh rekomendasi atau diskualifikasi terhadap pilihan agent lainnya. Pada kasus dunia nyata influence terjadi didalam sebuah kelompok tertentu yang memiliki sebuah hubungan seperti teman, keluarga lingkungan kerja dan sedikit kejadian acak dilingkungan dimana seseorang tersebut bersosialisasi. Pemodelan perilaku kali ini dibentuk dengan asumsi bahwa setiap agent memiliki kesempatan yang sama untuk mendapatkan dan melakukan influence terhadap agent lainnya. Influence terjadi karena jarak antar agent pada range tertentu dilokasi district yang sama dan probabilitas keinginan memberikan influence terpenuhi kemudian dilanjutkan keputusan dari probabilitas antara memberikan rekomendasi atau diskualifikasi produk. Berikut ini adalah rule aktivasi state untuk influence. Gambar 7 merupakan kerangka rekomendasi dan diskualifikasi agent.

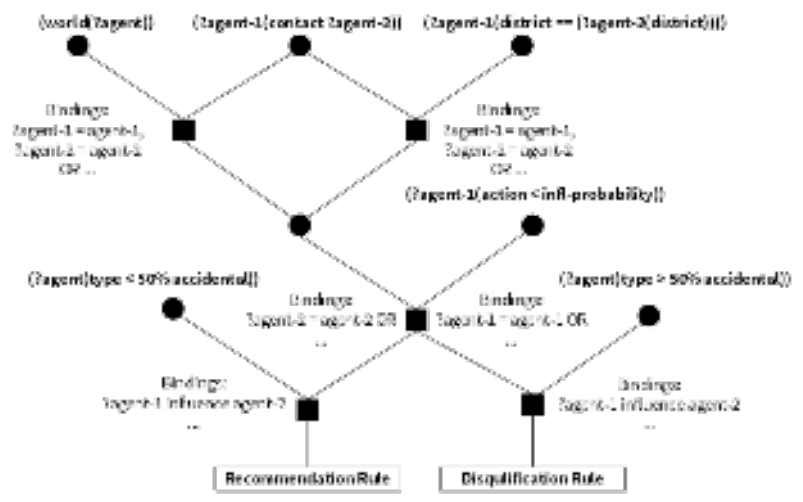

Gambar 7 Rule evaluasi influence

\section{b. Konstruksi aturan interaksi individu dan pemilihan produk}

Proses pemilihan produk melibatkan tahapan model perilaku konsumen dalam mengevaluasi kedekatan atribut yang dimiliki agent terhadap pilihan produk yang ada.

1. Cek state "buy product" aktif atau cek kondisi agent saat ini apakah dalam pemenuhan kebutuhan konsumsi.

2. Evaluasi motivasi terhadap pilihan produk.

3. Cek kemungkinan accidental action terpenuhi untuk agent memilih produk yang bertolak dengan aturan normal.

4. Tetapkan produk sebagai pilihan konsumsi saat ini.

5. Lakukan iterasi ini untuk kebutuhan konsumsi berikutnya sesuai selama simulasi berlangsung.

\section{PEMBAHASAN}

Pembentukan komponen game seperti konten akuntansi, suara, grafis, gameplay dikombinasikan sedemikian rupa sehingga mampu membawa misi utama serious game sebagai media alternatif belajar siklus bisnis dan akuntansi. Dalam implementasinya berikut ini difokuskan pada hasil dari penerapan teori sebelumnya untuk menciptakan game world dan proses simulasi.

\section{Hasil Simulasi Game}

Game membangkitkan cuaca, event, district, consumer, dan toko. Setiap agent diinisialisasi di district masingmasing sesuai personality trait, kemudian rule melakukan pengecekan terhadap state milik setiap agent, apakah telah menyelesaikan primary action sebagai student, worker, dan trader. Game juga mengecek apakah hari ini merupakan hari libur atau hari aktif, apakah agent membutuhkan makan, apakah agent stres, apakah agent harus pergi bermain, apakah agent harus pulang ke rumah. Agent diberikan kemampuan untuk menjelajahi game world dalam game tile isometric.

Kemampuan agent menghindari halangan (obstacle) dibuat dengan teknik searching pathfinding menggunakan algoritma $A^{*}$ sehingga menghasilkan jalur dengan jarak terpendek dari point-to-point coordinate tujuan. Finite state 
machine yang diberikan kepada agent mengontrol tingkah laku agent. Setiap agent memiliki role untuk berinteraksi dengan lingkungan. Aktivitas consumer dalam lingkungan game world ditunjukkan seperti pada Gambar 8 dimana consumer dapat berkunjuk ke suatu district dan saling memberikan influence kepada consumer yang lain.

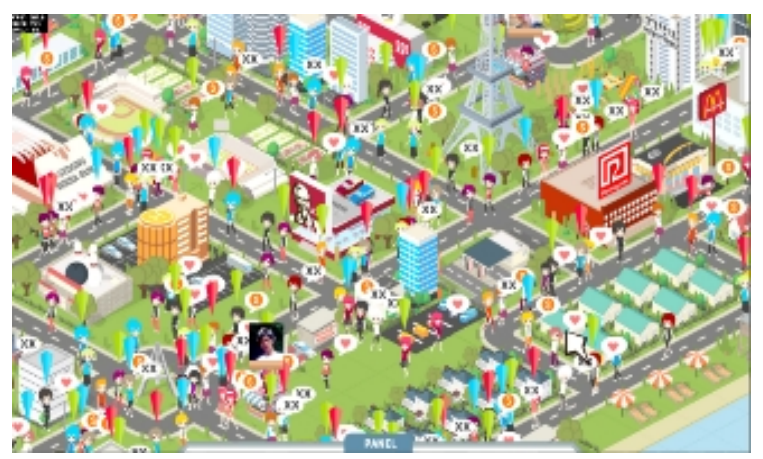

Gambar 8 Screenshot simulasi pasar dalam kondisi chaos

Simulasi dengan pengaturan yang sama dapat menghasilkan output yang berbeda, hal ini bukan karena rule dan state agent yang tidak konsisten, tetapi adanya kondisi acak dan accidental action yang membentuk agent lebih dinamis dengan kemungkinan agent keluar dari rule yang ditetapkan, tambahan kejadian pembelian juga terjadi dengan agent yang memiliki peran sebagai "freeman". Agent freeman digunakan untuk transaksi tidak terduga atau aktivitas accidental. Secara keseluruhan hasil simulasi dapat menunjukkan bagaimana agent membantu memperlihatkan fenomena daripada hasil pasti dalam sebuah record data.

\section{Hasil Variasi Simulasi}

Simulasi di uji menggunakan 3 jenis pengaturan parameter yang melibatkan 3 toko dengan membangkitkan 20 agent, pertama melihat hasil ketika 3 toko memiliki parameter harga, kualitas dan avertisement sama. Kedua, melihat hasil ketika mengatur kondisi ekstrim untuk salah satu toko. Ketiga melihat hasil ketika membuat situasi yang kompetitif. Simulasi mengambil data dalam 50 snapshot dari aktivitas toko seperti pembelian item dan market share.

\section{a. Simulasi dengan kondisi parameter setara}

Simulasi ini menghasilkan dominasi sepenuhnya pada toko 1 (Red). Setiap agent akan menghasilkan nilai motivasi $\operatorname{Max}\left(\mathrm{M}_{\mathrm{i}}\right)$ yang sama, ada 2 pendekatan yang bisa digunakan untuk menyelesaikan masalah ini, yaitu pemilihan produk secara acak atau memilih produk yang ditemukan pertama kali. Karena pengecekan dimulai dari produk toko 1 maka hasil simulasi akan selalu menghasilkan pilihan pada toko 1 kecuali jika terjadi accidental, yang mengakibatkan pilihan acak dibangkitkan dan produk lain memiliki kesempatan untuk dipilih juga.

\section{Sold Item : 50 Snapshot}

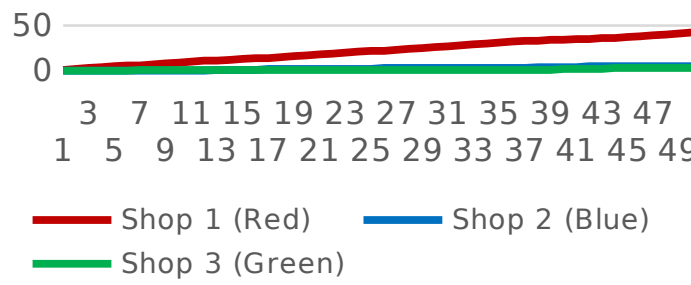

\section{Maket Share : 50 Snapshot}

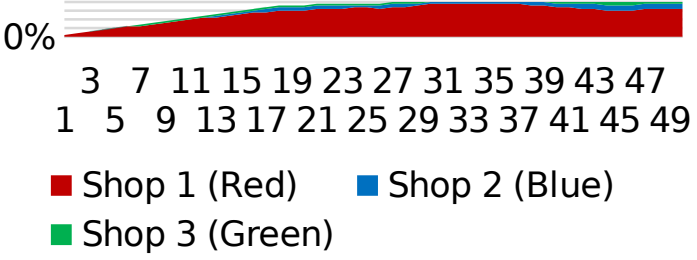

Gambar 9 Hasil simulasi parameter setara

Penjualan item didominasi oleh toko 1 (Red) diikuti beberapa pembelian acak untuk toko 2 dan toko 2. Market share dan pendapatan juga mengikuti jumlah pembelian produk. Total akhir nilai adalah toko 1 (Red) $2345 \mathrm{~K}$ dengan 42 transaksi dan rata - rata 69\% market share, toko 2 (Blue) $260 \mathrm{~K}$ dengan $5 \mathrm{x}$ transaksi dan rata - rata $7 \%$ market share, toko 3 (Green) $180 \mathrm{~K}$ dengan 3 transaksi dan rata - rata 4\% market share seperti yang ditunjukkan Gambar 9.

\section{b. Simulasi dengan kondisi ekstrim}

Simulasi kedua mencoba membuat kondisi ekstrim untuk salah satu toko dengan menurunkan harga dengan jarak yang cukup untuk membuat agent memilih produk dari toko tersebut. Uji coba ini dimaksudkan untuk menguji apakah simulasi dapat berjalan logis sesuai kondisi dunia nyata dimana konsumen mencoba memenuhi kebutuhannya dengan pilihan yang paling menguntungkan bagi mereka. Alternatif lain adalah dengan meningkatkan kualitas produk. Hasil simulasi kedua menghasilkan dominasi tipis untuk toko 3 (Green). Perbedaan total pendapatan antara toko 3 dan toko 2 juga tidak terlalu besar, mengingat harga dari produk di toko 3 lebih rendah.

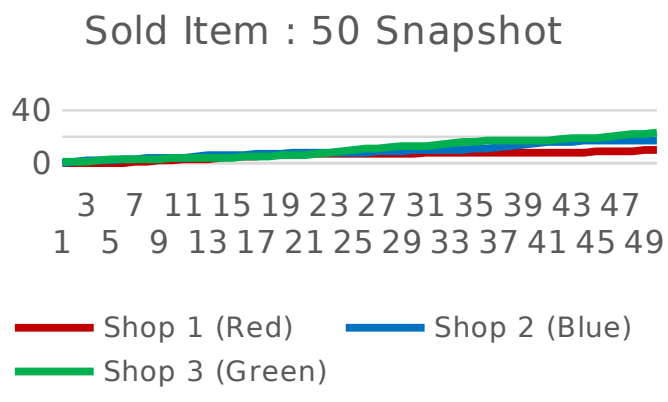




\section{Market Share : 50 Snapshot}

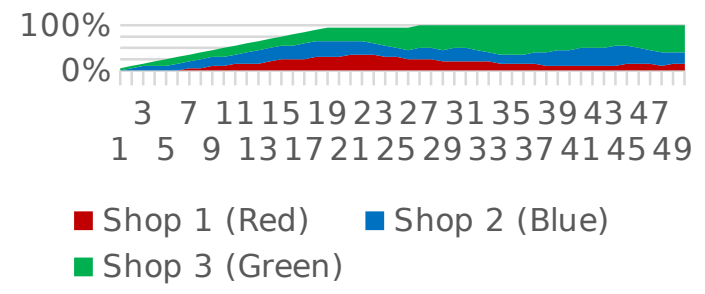

Gambar 10 Hasil simulasi kondisi ekstrim

Penjualan didominasi oleh toko 3 (Green). Pendapatan toko 2 dan toko 3 bersaing tipis. Total nilai toko 1 (Red) $475 \mathrm{~K}$ dengan 10 transaksi dan rata - rata $16 \%$ market share, toko 2 (Blue) $865 \mathrm{~K}$ dengan $17 \mathrm{x}$ transaksi dan rata rata $26 \%$ market share, toko 3 (Green) $925 \mathrm{~K}$ dengan 23 transaksi dan rata - rata $38 \%$ market share seperti yang ditunjukkan pada Gambar 10.

\section{c. Simulasi dengan kondisi kompetitif}

Simulasi ketiga mencoba membuat kondisi ketiga toko bersaing seimbang dengan kenaikan penjualan dan market share secara gradual bersama - sama. Uji coba ini dimaksudkan untuk menguji apakah simulasi dapat membuat penjualan dimasing - masing toko mendapatkan bagian dari dari total market share dan tidak tertinggal jauh dari pesaing yang lain. Total parameter harga dan kualitas diatur berdekatan, tetapi untuk kualitas disetiap produk berbeda agak jauh. Penjualan item didominasi oleh toko 3 (Green) diikuti toko 2 (Blue) dan toko 1 (Red). Grafik pendapatan produk menunjukkan kenaikan yang hampir bersamaan namun total yang berlipat dari hasil toko 1 kemudian toko 2 dan paling besar toko 3 .

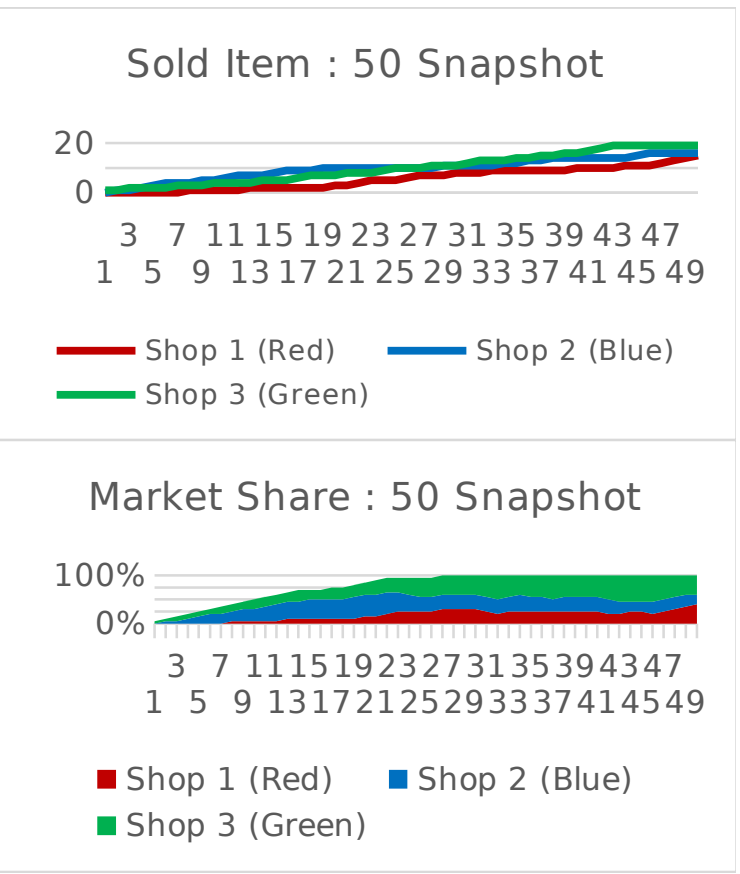

Gambar 11 Hasil simulasi kondisi kompetitif

Gambar 11 menunjukkan total akhir nilai dari simulasi ketiga adalah toko 1 (Red) $675 \mathrm{~K}$ dengan 15 transaksi dan rata - rata $18 \%$ market share, toko 2 (Blue) $925 \mathrm{~K}$ dengan 16 transaksi dan rata - rata 28\% market share, toko 3 (Green) $925 \mathrm{~K}$ dengan 19 transaksi dan rata - rata 33\% market share.

\section{KESIMPULAN}

Serious game tentang simulasi bisnis menggunakan pendekatan berbasis agent menghasilkan simulasi dan interaksi yang dapat memunculkan fenomena atau perilaku pengambilan keputusan konsumen dalam memilih sebuah produk. Agent-based system dapat digunakan sebagai alat untuk visualisasi tiruan kehidupan yang kompleks seperti manusia, hewan, lingkungan untuk digunakan sebagai alat pengambil keputusan yang sifatnya prediksi.

Hasil simulasi ini dijadikan konsep dasar game bisnis yang menghasilkan transaksi untuk menunjukkan siklus akuntansi yang berawal dari berbagai kejadian finansial seperti pembukaan toko pembelian material, asset, penjualan produk, penyewaan karyawan, pemasangan iklan dan lain sebagainya. Serious game dapat menjadi media alternatif untuk proses belajar dan latihan yang melibatkan berbagai topik, salah satunya adalah bisnis dan akuntansi.

\section{SARAN}

Pemodelan agent untuk simulasi dunia nyata yang melibatkan manusia menimbul keraguan pada aturan yang dimiliki pada sebuah agent. Manusia merupakan makhluk yang random, sulit diprediksi dan penuh ketidakpastian. Dalam penelitian ini agent hanya diberi attribute dan behavior sederhana dalam model pengambilan keputusan pembelian. Diperlukan pemikiran yang mendalam dan aturan yang lebih detil untuk menciptakan kondisi seperti dunia nyata. Pengembangan konsep serious game sendiri perlu dilakukan uji coba untuk menentukan gameplay yang tetap menarik seperti entertainment game serta dibutuhkan teknik khusus untuk mengukur hasil knowledge transfer yang diberikan dari game kepada pemain.

\section{UCAPAN TERIMA KASIH}

Paper ini disusun untuk memenuhi salah satu syarat memperoleh gelar sarjana (S1) pada Program Studi Sistem Informasi, Jurusan Sistem Informasi, Universitas Jember. Penulis mengucapkan terima kasih kepada Drs. Slamin, M.CompSc., Ph.D selaku Ketua Program Studi Sistem Informasi Universitas Jember, Dr. Saiful Bukhori, S.T., M.Kom sebagai Dosen Pembimbing Utama, dan Nelly Oktavia A. S.Si., M.T sebagai Dosen Pembimbing Asisten serta seluruh dosen Program Studi Sistem Informasi Universitas Jember.

\section{DAFTAR PUSTAKA}

[1] Ajzen I, F. (2005). The Influence of attitudes on behavior. In:Albarracin D, B. Johnson B, Zanna $M$, editors. The handbook of attitudes, Mahwa, NJ. Erlbaum.

[2] Becker, R. (2011, January 22). Interactive Games for Business Training. Becker Multimedia Paper.

[3] Bose, J. (2013, May 7). Creating Isometric Worlds: A Primer for Game Developers. Retrieved March 27, 
2014, from Tutsplus: http://gamedev.tutsplus.com/ tutorials/ implementation/creating-isometric-worlds-aprimer-for-game-developers/

[4] Campos, A., Canuto, A., Fernandes, J., \& Moura, E. (2004). MASIM: A METHODOLOGY FOR THE DEVELOPMENT OF AGENT-BASED. Proceedings 16th European Simulation Symposium.

[5] Cui, X., \& Shi, H. (2011). A*-based Pathfinding in Modern Computer Games. IJCSNS International Journal of Computer Science and Network Security, VOL.11 No.1, 125-130.

[6] Engel, J., Blackwell, R., \& Miniard, P. (1995). Consumer Behavior. 8th ed. Philadelphia: The Dryden Press.

[7] Granic, I., Lobel, A., \& Engels, R. (2013). The Benefits of Playing Video Games. American Psychological Association Vol. 69, No. 1, 66-78.

[8] Gunter, G., Kenny, R., \& Henry, E. (2010). A Case for a Formal Design Paradigm for Serious Games.

[9] Ladenhauf, D. (2014, 12 24). Computer Graphics: Depth Sort Algorithm (Newell's Algorithm). Retrieved from Dieter Ladenhauf Blogs: http://www.dieterladenhauf.com/blog/2012/03/depthsort-algorithm-newells-algorithm/

[10] Macal, C., Chan, W., \& Son, Y.-J. (2010). AGENTBASED SIMULATION TUTORIAL SIMULATION OF EMERGENT BEHAVIOR AND DIFFERENCES BETWEEN AGENT-BASED SIMULATION AND DISCRETE-EVENT SIMULATION. Proceedings of the 2010 Winter Simulation Conference, 135-150.

[11] Mursiti, S., Fardhyanti, D., Cahyono, E., \& Sudarmin. (2006). MISCONCEPTION REMEDIATION OF ATOMIC ORBITAL, MOLECULAR ORBITAL, AND HIBRIDIZIATION CONCEPTS BY COMPUTER ASISSTED INSTRUCTION WITH ANIMATION AND SIMULATION MODEL. Indonesian Journal of Chemistry, 104-110.

[12] Patel, A. (2014, 12 Tuesday). Heuristic. Retrieved from Standford Edu: http:/theory.stanford.edu/ amitp/GameProgramming/ Heuristics.html

[13] Patel, S., \& Schlijper, A. (2004). Models of consumer behavior. ESGI.

[14] Sakellariou, I. (2012). Turtles as State MachinesAgent Programming in NetLogo using State Machines. CAART (2), 375-378.

[15] Suyanto. (2007). Artificial Intelligence Searching, Planing dan Learning. Bandung: INFORMATIKA.

[16] Ulbinaitè, A., Kučinskienė, M., \& Le Moullec, Y. (2011). Integration of the Decoy Effect in an AgentBased-Model Simulation of Insurance Consumer Behavior. International Conference on Software and Computer Applications IPCSIT vol.9 IACSIT Press, Singapore, 153-157.

[17] W. Reynolds, C. (1999). Steering Behaviors Fo Autonomus Characters. Game developers conference, 763-782.
[18] Wagner. (2006). Modeling Software with Finite State Machines: A Practical Approach. Auerbach Publications.

[19] Zhang, T., \& Zhang, D. (2007). Agent-based simulation of consumer purchase decision-making and the decoy effect. Journal of Business Research 60, 912-922. 